\title{
Open Innovation and Business Model: A Brazilian Company Case Study
}

\author{
Elzo Alves Aranha ${ }^{* 1}$, Neuza Abudd Prado Garcia ${ }^{2}$, Giselle Corrêa ${ }^{3}$
}

\begin{abstract}
Open Innovation is increasingly being introduced in international and national organizations for the creation of value. Open innovation is a practical tool, requiring new strategies and decisions from managers for the exploitation of innovative activities. The basic question that this study seeks to answer is linked to the practice of open innovation in connection with the open business model geared towards the creation of value in a Brazilian company. This paper aims to present a case study that illustrates how open innovation offers resources to change the open business model in order to create value for the Brazilian company. The case study method of a company in the sector of pharma-chemical products was used. The results indicate that internal sources of knowledge, external sources of knowledge and accentuate working partnerships were adopted by company as strategies to offer resources to change the open business model in order to create value.
\end{abstract}

Keywords: open innovation; open business model; internal and external sources of knowledge; partnerships.

Submitted: April 15th 2015/ Approved: December 2nd 2015

\section{Introduction}

Open innovation is increasingly being introduced in international and national organizations for the creation of value (Chesbrough \& Rosenbloom, 2002; Lee, Olson, \& Trimi, 2012; Morgan \& Finnegan, 2008; Ndou, Vecchio, \& Schina, 2011). The creation and delivery of value through innovation has become the rule for post-modern companies in the context of the market, driven mostly by two forces, complexity and the rate of change (Hatch, 1997). The company can move between a moderately dynamic market and a high speed market (Eisenhardt \& Martin, 2000) that requires an ability to integrate, build and re-configure the internal and external capabilities to respond quickly to changes in the market (Teece, Pisano, \& Shuen, 1997).

Teece et al. (1997) have denominated them as dynamic capabilities, since they refer to a company's ability to identify innovative ways of obtaining a competitive advantage in the market. The quest to introduce innovation drives the company to capture knowledge outside its boundaries, which can be considered as a dynamic capabilities of the company. The stock of information and knowledge captured externally is transferred to the company and is a useful tool for the creation and delivery of value, increasing the growth of the organization, the conquest of new domestic and international markets, and contributing to increased performance and profits. This movement to capture knowledge from outside the company is one of the driving elements in the creation of value for the company, because it makes operation of dynamic capabilities visible, in the sense of understanding and mapping opportunities and threats, grabbing opportunities to maintain competitiveness through the increase, combination, protection and reinvention of the business model (Teece, 2007; Teece et al., 1997).
Innovation as a vector that expands opportunities and performance in the organization, and which promotes changes in the balance of the market, was first analyzed by Schumpeter (1934), who proposed disruptive innovation as a core element of opportunities for companies. According to Schumpeter (1934), it is only through innovation that the company is able to transform the market from a status of equilibrium to a dynamic state, which turns innovation into the main function of the post-modern company, since innovation touches on the trajectory of growth and profits by capturing and delivering value to customers (Drucker, 1985). Tidd, Bessant and Pavitt (2005) proposed the innovation management model as a path to be followed by organizations so as to integrate technological change, market change and organizational change, and they point out that collaboration is one of the basic components of the innovation model. The collaboration with actors external to the firm is essential in the pursuit of new external knowledge. It was Chesbrough (2003a, 2003b; 2003c), however, who questioned the closed innovation model used by organizations, which was based on internal sources of knowledge and unable to accelerate the creation and delivery of value, and also of performance and profit. The open innovation proposal defends that knowledge coming from external sources at the same level as knowledge from internal sources, intellectual property focused on market sales, company outputs focused on the external market and the business model are central to the company (Chesbrough, 2006; West, Salter, Vanhaverbeke, \& Chesbrough, 2014).

The growing and vast international academic production on open innovation demonstrates an increasing international interest in investigating new models, practices, approaches and tools for organizations. Nevertheless, the vast majority of articles on open innovation still have unanswered questions. Among these components of reflec-

1,3 Production Engineering and Management Institute, Federal University of Itajubá, Itajubá, Minas Gerais, Brazil,

2 Nove de Julho University, São Paulo, Brazil

*Corresponding author: eaaranha@unifei.edu.br

ISSN: 0718-2724. (http://jotmi.org)

Journal of Technology Management \& Innovation @ Universidad Alberto Hurtado, Facultad de Economía y Negocios. 
tive elements, three groups of questions stand out that deserve to be investigated. First, there are the issues related to the understanding of the importance of open innovation in high-technology industries; the second set of issues is linked to the study of how companies implement innovation in practice (Chiaroni, Chiesa, \& Frattini, 2011; Ebersberger, Bloch, Herstad, \& Van de Velde, 2012). At the same time the reflections by Mortara and Minshall (2011) gain relevance, who were emphatic in emphasizing the need for the expansion of research on the way in which companies implement open innovation in an attempt to contribute to the fulfillment of this gap. Their study of 43 firms in different sectors looks at how companies move from the practice of closed innovation toward open innovation (Mortara \& Minshall, 2011).

The third group of issues is connected with the implementation of the open innovation practice in conjunction with the implementation of the open business model, which is geared toward the creation of value. In the literature, there are studies that seek to analyze business models and open innovation, open innovation strategies with dimensions of the business model (Saebi \& Foss, 2014), open innovation and dynamic business models (Gay, 2014) and open innovation and open business models (Frankenberger, Wiblen, \& Gassman, 2014; Weiblen, 2014). However, there are few articles that analyze the connections between open innovation and the business model and their influence on the value creation process. By stating that open innovation has the business model at its hart and that it is essential for the creation of value and profit through technology (Chesbrough, 2003b), a question emerges regarding the about practices or strategies, supported by the same open innovations adopted in companies and connections with the generation of benefits and improve the company performance. However, for the capture of internal and external knowledge, and concomitantly with the development of partnerships arising from open innovation and open business models, would they contribute to the creation of value in Brazilian companies? The investigations in this direction will bring new support for the debate about future directions.

The basic question that this study seeks to answer is linked to the practice of open innovation in connection with the open business model geared towards the creation of value in a Brazilian company. It intends to answer the following question: how should the acquisition of internal knowledge, the acquisition of external knowledge and partnership development, supported by open innovation, provide resources to change the open business model in order to create value for the Brazilian company? The answer to this basic question will contribute to fill the gap pointed out earlier, offering analyses and reflections on the connections between open innovation, the open business model and value creation.
This paper aims to present a case study that illustrates how open innovation offers resources to change the open business model in order to create value for the Brazilian company. In particular, it intends to analyze how the acquisition of internal knowledge, and the acquisition of external knowledge and partnership development, supported by open innovation, should provide resources to change the open business model in order to create value for the Brazilian company. The case study of a company in the sector of pharma-chemical products demonstrates that open innovation (acquisition of internal knowledge, acquisition of external knowledge and partnership development) paves the way for the reinvention of the business model and promotes value creation.

\section{Methods and Techniques}

The reflexive methodology (Alvesson \& Sköldberg, 2000) guided the analysis of the international literature on open innovation, open business models and value creation. The study was exploratory and qualitative. Three steps were adopted for the development of this study. In the first step, searches of academic articles were carried out in the CAPES portal using the search-by-subject option. First, the search results for the terms open innovation, open business model and value creation were mapped. Those articles were selected that connected open innovation with open business models and value creation. For open business models, the article by Weiblen (2014) and Frankenberger et. al. (2014) was selected, which seek to establish a distinction between open innovation, open business models and business models. For value creation, attention was focused on the studies by Anderson, Narus and Narayandas (2009).

In the second step, the framework of analysis was designed, identifying the independent and dependent variables according to the framework of analysis presented in figure 1 (Calia, Guerrini, \& Moura, 2007). Then, the important elements in the literature on open innovation, open business models and value creation were identified. In open innovation, the ways in which the processes for the acquisition of internal knowledge, in parallel with external knowledge and partnerships, offer resources for changing the open business model and allow for the creation of value. The business model was analyzed based on open innovation and value creation.

In the third step, information was gathered on the company's website and other printed and electronic media. The independent variables (search for external knowledge, search for internal knowledge and relationships) that offer resources for the dependent variable (value creation) through the open business model, were analyzed. According to Yin (2005), a case study presents the main research question and the sources of information that contribute to answering this research question. 


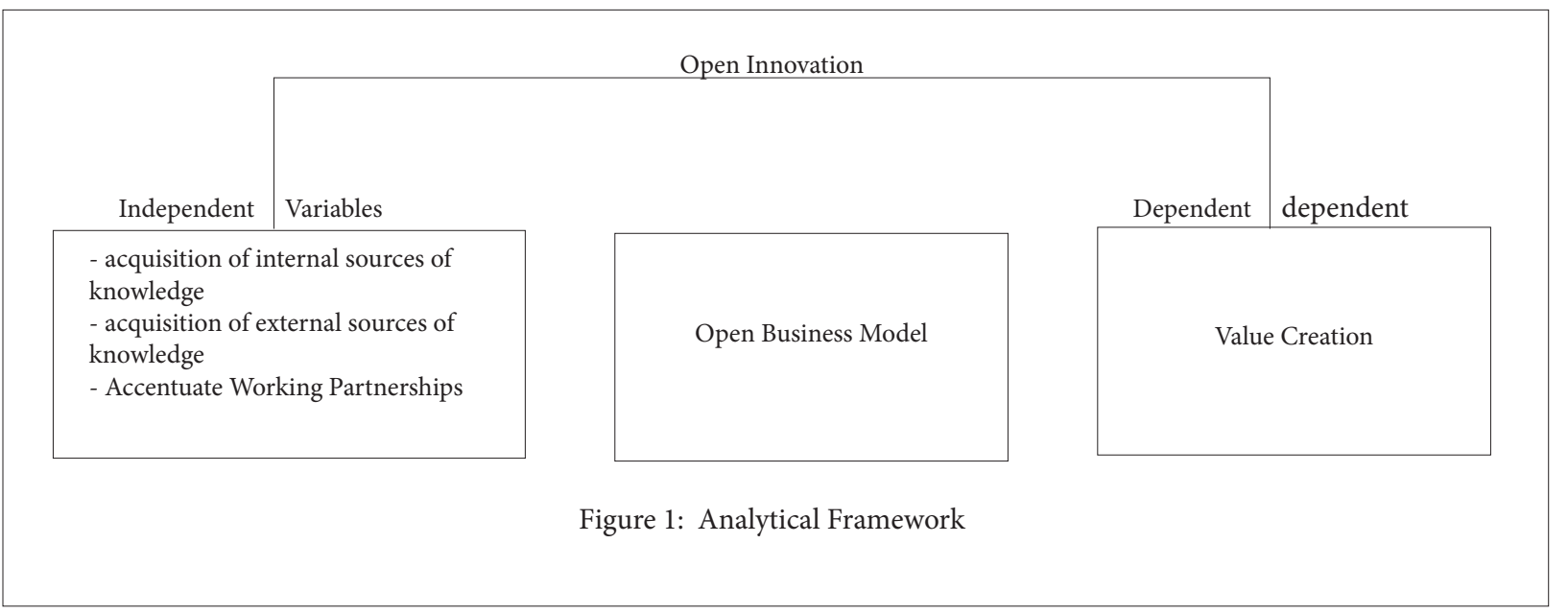

\section{Literature Review}

\subsection{Open Innovation}

Chesbrough (2003a) established the first distinction between open and closed innovation by highlighting that innovation was not inducing the creation of value or increasing profits for companies. According to Chesbrough (2003a), the new era of open innovation is based on the principles of: acquisition of external knowledge, acquisition of internal knowledge, business models and outflows. Acquisition of external knowledge is given its rightful place, at the same level and balanced with internal knowledge. In addition, Chesbrough (2003a; 2003b; 2003c) states that open innovation must be rooted in the notion that research carried out outside the company may enable the generation of value for the company and its partners. Open innovation is a practical tool, requiring new strategies and decisions from managers for the exploitation of innovative activities (Huizingh, 2011). Since it's a practical tool, innovation requires new strategies and decisions from managers for the exploration of innovative activities, improving the flow of external knowledge and information inputs and transforming them into results that improve the company's profit (Huizingh, 2011). Given that open innovation is a management practice tool, it refers to the arena of confrontation between open and closed innovation, the input and output activities of innovation processes and the distinction between processes and results (Huizingh, 2011).

Pressured by moderately dynamic, but also very dynamic and high speed markets, the company may adopt open innovation, considering its dynamic capabilities to identify new ways of obtaining a competitive advantage, analyzing both its strengths and weaknesses and threats and opportunities (Eisenhardt \& Martin, 2000; Teece et. al., 1997). In closed innovation, the company seeks to increase its competitive advantage by introducing innovations with resources generated within the company, while open innovation contributes to increasing competitive advantage by seeking knowledge and technologies external to the company. Open innovation involves three essential aspects: (I) acquisition of internal sources of knowledge; (ii) acquisition of external sources of knowledge; (iii) accentuate working relationships.

\subsubsection{Internal Sources of Knowledge}

Companies have various reasons to adopt the practice of open innovation. A study conducted by Van de Vrande, De Jong, Vanhaverbeke and De Rochemont (2009) with 605 micro and small innovative Dutch companies pointed out the main reasons that lead companies to adopt open innovation practices. The main reasons include the alignment of competencies with the company's activities, the improvement of the innovation process, integrating it with the market, the integration of new technologies, the development of new markets and customers, and the increase in market share. These reasons may not be achieved when the company adopts a closed model of innovation by itself. These reasons lead the company to adopt tools that allow for the assessment of internal resources.

Barney (1991) argues that tangible and intangible resources of the firm, such as technical knowledge, equipment, people and capital, can generate value for third parties and sustain a competitive advantage. This perspective that focuses on an internal outlook on the firm's resources is insufficient to maintain the company on course in the search for a competitive advantage. The internal resources of the firm need to go through a test to identify their ability to generate value for customers and partners. The test is carried out with the main competitors, considering whether their imitability, durability, appropriability, substitutability and superior competitiveness as well as their competitors are found in an environment external to the firm (Anderson et. al., 2009). Another crucial point is whether the tests of the resources will enable the analysis of strengths and weaknesses compared to the main competitors.

The acquisition of internal sources of knowledge only contributes to value creation and the increase in the company's profit when it is compared with the resources of external competitors (Anderson et. al., 2009). Companies implement various strategies to leverage their internal knowledge, such as the licensing of intellectual property developed internally and the involvement of employees in research \& development (R\&D) (Van de Vrande et. al., 2009). However, even if the licensing of internally developed technology to another company may be an important strategic benefit that generates revenues for the 
company and represents the sale of residual knowledge, it may also prove restrictive and compromise the performance and profit generation of the company (Lichtenthaler, 2010).

\subsubsection{External Sources of Knowledge}

Teece (2007) emphasizes that dynamic capabilities are rooted in the acquisition of resources external to the firm, in such a way that it may understand and map its opportunities and threats, and seize the opportunities to maintain competitiveness by increasing, combining, protecting and reinventing its business model (Teece, 2007; Teece et.al., 1997). The acquisition of knowledge external to the firm occurs as a result of the close relationship with the customer, the development of networks of relationship, external participations, outsourcing of $\mathrm{R} \& \mathrm{D}$ and it may bring intellectual property licenses to the company (Young, Hewitt-Dundas, \& Roper, 2008).

External participations are represented by partnerships and collaborations with external companies and organizations in order to develop projects of mutual interest. The acquisition of external knowledge involves a continuous effort by the company (Chen, Chen, \& Vanhaverbeke, 2011). Porter and Newman (2011) state that the knowledge from $R \& D$ obtained from outside the company involves a set of steps that involve a literature review, the characterization of the research profile, the mining of technology, the discovery of structured knowledge, and discovery based on the literature. The external knowledge acquisition process also involves the search for technologies, which should be chosen and analyzed regarding their main applications and features, and their fit to the needs, desires and demands of the market (Tickle, Adebanjo, \& Michaelides, 2011).

\subsubsection{Accentuate Working Partnerships}

Anderson et. al. (2009) state that companies can develop relationships at three levels. The transactional level, which only involves transactions of basic products with a focus on prices. The collaborative level, which involves a mutual interest in the development of solutions, products, services, technologies and processes in various sectors for a variety of purposes. In the collaborative level, the company can move up to the level of partnership, developing strong partnerships in order to establish economic, social, service, technical and cost reduction benefits, and to increase the value added of its operations.

Relationships develop inside business networks that consist of a set of two or more companies that are connected through mutual interests. In open innovation, business relationships and networks in the external environment are strategic for the survival of the company. Knudsen and Mortensen (2011) highlight that the most important external partners in new product development projects are suppliers, customers, universities and research centers, consultants and competitors.

These relationships develop through people and multiple leaders, who organize the business networks and innovation community (Klerkx \& Aarts, 2013). In new projects that involve the development of solutions for customers, a strong interaction between the parties, with the intensive sharing of knowledge and communications with the defini- tion of technology transfer mechanisms, has become essential (Hsieh \& Tidd, 2012). However, small businesses involve themselves less in $\mathrm{R} \& \mathrm{D}$ collaboration processes than medium-sized enterprises (Chiaroni et. al., 2011).

\subsection{The Open Business Model}

Weiblen (2014) emphasizes that Chesbrough (2003a) associates the open business model with open innovation, highlighting that the pursuit to accelerate internal innovation in the firm is obtained through the development of an environment of collaboration and partnership with institutions in research and development (R\&D) in order to develop and commercialize intellectual property (IP) and create economic value. According to Weiblen (2014) this notion in which the open business model intrinsically associates the design or architecture of the value creation, acquisition and delivery mechanisms through open innovation with $\mathrm{R} \& \mathrm{D}$, is restricted and limited. Based on the analysis of various academic articles, Weiblen (2014) manages to counter this notion, Chesbrough's position, extracting the main elements of the open business model, in addition to narrowing its scope and purpose. According to Weiblen (2014), the term 'openness' in open business models is grounded on the logic of the firm's collaboration with its ecosystem. This collaboration is very pronounced and guides the entire design of the firm's representation model, in which strategic decisions to collaborate with the ecosystem are focused on the creation and delivery of value (Frankenberger et.al., 2014).

According to Weiblen (2014), the open business model is a subclass of business models in which collaboration plays a central role in order to create and capture value for the company. The strong collaboration of the firm with the other partners of the ecosystem involves not only R\&D institutions or transactions, but the partnership modality. A partnership seeks to lower total costs or to increase value over time so as to achieve mutual benefits through economic, technical, social and service benefits arising from the use of the company's proprietary platform by small partners to create value for the customer (Anderson et. al., 2009). Lowering total costs or increasing value over time to achieve mutual benefits is associated with the co-creation process between the firm and its ecosystem (Anderson et. al., 2009). Collaboration, therefore, plays a key role in the open business model, providing a favorable environment for co-creation between the firm and its ecosystem through the use of mutual resources which are focused on the creation and delivery of value (Weiblen, 2014).

Calia et. al. (2007) investigated the innovation network in connections with business model identifying the independent variables (relationship structures, innovation typology and innovation network dynamic) and dependent variables (business internationalization and company growth) in Brazilian metallurgy company. Calia et. al. (2007) adopted business model framework (Morris, Schindehutte, \& Allen, 2005) to describe the metallurgy company's business model in connections with innovation network. However, the present study adopts three different kind of business model framework (Chesbrough \& Rosembaum, 2002; Morris et. al., 2005; Osterwalder, Pgneur, \& Tucci, 2005). The conceptual framework of the open busi- 
ness models proposed by Chesbrough and Rosembaum (2002), Osterwalder et. al. (2005), and Morris et. al. (2005) each contain basic components that structure and characterize each one of these models. The models differ in terms of basic components. However, there are some basic components that are common and present in all models. The answers to some questions are crucial to see which basic component are common to the three models: (1) how does the company create value? (2) For whom does the company create value? (3) What are the sources of external and internal knowledge for the creation of value? (4) How does the company develop partnerships to create value? These questions will be answered in the case study analysis.

\subsection{Value Creation}

The concept of value used in this study comes from the field of Marketing. Anderson et. al. (2009) describe value as the sum of all the economic, technical, service and social benefits that a customer receives in exchange for a price he pays for a market offer. According to Anderson et. al. (2009) the value received by the customer needs to be compared and be superior to the value delivered by the best alternative offered by a competitor. This concept of value is directly associated with the customer. However, the concept of shareholder value has been used by executives in order to evaluate business performance. Shareholder value represents the economic return arising from the implemented decisions and strategies that exceeds the capital costs employed in the business (Anderson et. al., 2009). Value creation is directly associated with the customer and the company.

Low (2000) proposes a model that involves nine non-financial performance categories that determine the creation of value. The value creation index represents the sum of all main intangible assets that the company can evaluate. The nine categories of the model are: (1) innovation, (2) quality, (3) customer relations, (4) management capabilities, (5) alliances, (6) technology, (7) brand value, (8) employee relations, and (9) environmental and community aspects. These categories enable the measurement of the firm's intangible assets, providing information on the company's performance. Morgan and Finnegan (2008) state that the company creates value for the company itself through efficiency in business, the availability and sharing of knowledge with the community and customers, and the development of solutions for these actors. The new products meet the needs, desires and requirements of the customers. The company creates value for the customer when it increase the level of satisfaction and increases collaboration, participation and the delivery of benefits.

\section{Case Study}

\subsection{Case Study Protocol}

The literature review enabled the identification of the main elements involved in open innovation: (i) acquisition of internal sources of knowledge, (ii) acquisition of external sources of knowledge and (iii) relationships, since these elements are represented in the cognitive device, called the open business model, seeking the creation of value. Figure 1 sets out the framework of this analysis in independent vari- ables (search for external knowledge, search for internal knowledge and relationships), which offer resources to the open business model which affect the dependent variable (value creation).

The case study seeks to illustrate how open innovation offers resources to change the open business model in order to create value for the Brazilian company. In particular, it intends to analyze how the acquisition of internal knowledge, the acquisition of external knowledge and partnership development, supported by open innovation, provide resources to change the open business model in order to create value. The case study seeks to answer the following question: how do the acquisition of internal knowledge, the acquisition of external knowledge and partnership development, supported by open innovation, provide resources to change the open business model in order to create value for the Brazilian company? The information on the company in the pharmachemical sector was gathered from the company's website, and from newspapers and magazines. The official name of the company will not be mentioned in this study. The name Alpha was adopted to designate the case study company.

\subsection{The Alpha Company}

The Alpha Laboratory is a Pharmachemical, Pharmaceutical, Biotechnology, Research, Development and Innovation complex with $100 \%$ Brazilian capital. The Alpha was founded in the beginning of the 1970s as a nursing home in the city located in the heartland of São Paulo State. To meet the internal demand for medication, the four founding physicians of the nursing home started a laboratory with a production capacity exceeding the internal demand for consumption. This surplus was then sold. Innovation was at the heart of Alpha since its founding. In 1976, it developed Haloperidol, an anti-psychotic that was being produced through a monopoly of a multinational company.

The company operates in the following business sectors: (i) hospitals, with products used in the environments of $95 \%$ of Brazilian hospitals; (ii) pharmacies, with products sold in more than 40 thousand pharmacies; (iii) corporis, involving products for dermatology, aesthetics and derma-cosmetics; (iv) biological products focused exclusively on radiology, hemodialysis, surgery, oncology, and dentistry clinics and with asepsis brushes for the hands of surgeons; (v) generics, with products and medication intended for: psychiatry, neurology, cardiology, gynecology, ophthalmology, and dermatology, among others. The company develops products for the business areas of anesthesia, erectile dysfunction, AIDS, central nervous system (bipolar disorders, schizophrenia, depression), pain and inflammation, dermatology and aesthetics. The company sells its finished products and raw materials to more than 30 countries. Its main markets are Latin America, Asia, Africa and the Middle East. Its main products are anesthetics and its adjuvants, analgesics, psychiatric products and antiretroviral drugs.

The pharmaceutical department totals more than $\mathrm{R} \$ 160$ million in investments, with 35 thousand square meters of constructed area and a fully automated plant, offering safety for all types of drugs. The pharmaceutical departments also counts with another plant of 16 thousand square meters for the production of solid, semi-solid, oral, 
injectable and eye drop drugs. Its second department, the center for research, development and innovation, has invested in the order of R\$ 30 million and was opened in 2009 . There are currently 29 projects in progress, 14 of which are incremental innovations and 15 radical innovations that are unprecedented in the world. The center is made up of 105 scientists and 25 highly specialized technicians. The company currently has more than 76 patents until the end of 2014. Until February 2014, the lab had 152 patent applications. The pharmachemical division was formed in 1983 and at the beginning of 1988 a massive investment was made in the research, development and innovation of active pharmaceutical inputs of high value-added that didn't exist in the national market or that were listed as inputs subject to import quota.

Currently, the Laboratory has more than 25 strategic partnerships with universities, research institutes and government agencies. There are more than 11 partnerships with universities. In 2013, Alpha had $\mathrm{R} \$ 1.4$ billion in revenues, which places the company among its major competitors in industry sector. The reinvention of the business model was the main factor for its growth. The partnership with research institutes, whether from universities or not, governments, development promotion agencies and health professionals, has always been on the strategic agenda of the company.

\subsection{Case Analysis}

The acquisition of internal sources of knowledge, external sources of knowledge and relationships were adopted as strategies by Alpha to pave the way for the company's growth, internationalization of its market and value creation. The inauguration of the center for research, development and innovation in 2009 reinvented Alpha's business model. The strong partnerships with universities enabled the acquisition of high quality sources of knowledge, contributing to the development of new products and new markets.

Considering the main common components of the conceptual frameworks of open business models proposed by Chesbrough and Rosembaum (2002), Osterwalder et. al. (2005), and Morris et. al. (2005), the next step is to describe the business model of Alpha. The description of the main common basic components of the business model (Calia et. al., 2007) will enable the illustration of how the acquisition of internal knowledge, the acquisition of external knowledge and partnership development, supported by open innovation, provide resources to change the open business model in order to create value. This description is linked to the following questions:

(1) how does the company create value? - Alpha creates value by delivering high-quality products that require research, development and innovation. The creation of value was intensified based on the deployment of the center for the development of research and innovation.

(2) For whom does the company create value? - The company creates value for customers in Brazil and in more than 30 countries, delivering high-quality and knowledge and technology intensive raw materials and finished products.
(3) What are the sources of external and internal knowledge for the creation of value? - The acquisition of opportunities in the external environment of the company enables the extraction of external knowledge, which passes to the internal environment of the company, increasing value creation. On the other hand, the creation of the center for research, development and innovation intensified the expansion process with the participation of 105 scientists and 25 highly skilled technicians. The company currently has more than 76 patents until the end of 2014. Until February 2014, the lab had 152 patent applications filed.

(4) How does the company develop partnerships to create value? Currently, the Laboratory has more than 25 strategic partnerships with universities, research institutes and government agencies. There are more than 11 partnerships with universities. The projects developed with universities are synchronized with the center for research, development and innovation. The generation of innovative knowledge through patents enhance the creation of value.

\section{Findings}

According to analytical framework presented in figure 1 (i) acquisition of internal sources of knowledge, (ii) acquisition of external sources of knowledge and (iii) accentuate working relationships are important elements, supported by open innovation, identified in the literature review. Based on case analysis (multiples sources of information of Alpha company) three important factors provide resources to change the open business model in order to create value for the Alpha Brazilian company. The exploratory and qualitative study demonstrated how independent variables can offer resources to the open business model which affect the dependent variable.

The study identified the connections between open innovation, open business model and value creation. In particular, it illustrated that Alpha company adopted strategies based on acquisition of internal sources of knowledge, acquisition of external sources of knowledge and accentuate working relationships from open innovation to reinvent business model and increase value creating to the customers. The Alpha company adopted open business model. The quality of the causality relations were anchored in: (i) Open innovation literature review; (ii) Open business model concept (Frankenberger et. al., 2014; Weiblen, 2014) and main common components of the conceptual frameworks of open business models proposed by Chesbrough and Rosembaum (2002), Osterwalder et. al. (2005), and Morris et. al. (2005); (iii) Value creation concept (Anderson et. al., 2009). However, the present study was qualitative and findings need to be validated in future studies by quantitative analysis (Calia et. al., 2007).

\section{Concluding Remarks}

When thinking about innovation, one should first reflect on the "Post-Industrial Society" scenario, a term coined by Alain Touraine (1997), that is characterized by the replacement of an economy based on industry by another in which the service sector has a greater participation. Touraine was one of the main intellectuals to take a critical 
look at the privatization, capital internationalization, economic liberalism and social change processes. This theorist considers that the fragmentation of the city and of the subject brings other strategies to the fore, which not only imply social democratic inclusion, but also possibilities for resistance and overcoming challenges. As such, he recovers the individual, who should not remain unconnected from the subject. For this duality is indicative of a rupture, because it puts the subject outside of history, with this overlap having significant implications for the historical narrative. And in an attempt to look forward to impasses caused by globalization, which are leading to an axis of domination between the owners of capital and the marginalization of those who don't have capital, the way that is pointed out implies a re-thinking of these new media forms of local and global space in a common dimension of humanitarian goals and objectives, seeking more growth and social progress. In this dimension, the perspective is rekindled of intellectual capital as one of these big challenges that companies should face if they are committed to advances and new directions. The question is then, how does one promote a reflexive perspective so that the actors in day-to-day activities may have an understanding in and of the empirical-inductive field, with a symbolic outlook? What would be the determinant conditions that would enable a mediation between thought and language? Would they exist based on facilitating situations? Does the act of curiosity and bewilderment in relation to the object to be observed imply an act of reading? But in which dimension? What is its nature?

Open innovation in this post-modern and post-contemporary context is increasingly being introduced in international and national organizations for the creation of value. The creation and delivery of value through open innovation has become the rule for post-modern companies in the context of the market, driven mostly by two forces, complexity and the rate of change. The company can move between a moderately dynamic market and a high speed market that requires an ability to integrate, build and re-configure the internal and external capabilities to respond quickly to changes in the market.

Based on the case study, one can infer that the acquisition of internal sources of knowledge, external sources of knowledge and relationships were adopted as strategies by Alpha to pave the way for the company's growth, internationalization of its market and value creation. The inauguration of the center for research, development and innovation in 2009 reinvented Alpha's business model. The strong partnerships with universities enabled the acquisition of high quality sources of knowledge, contributing to the development of new products and new markets. As such, it will be necessary to promote new contours for inventive-innovative processes.

\section{References}

Alvesson, M., \& Sköldberg, K. (2000). Reflexive Methodology: new vistas for qualitative research. London: Sage.

Anderson, J., Narus, J., \& Narayandas, D. (2009). Business market management: understanding, creating, and delivering value. 3rd. edition. Upper Saddle River, New Jersey: Prentice Hall.
Barney, J. B. (1991). Firm Resources and Sustained Competitive Advantage. Journal of Management, 17(1), 99-120. doi: $10.1177 / 014920639101700108$

Calia, R.G., Guerrini, F.M., \& Moura, G.L. (2007). Innovation networks: From technological development to business model reconfiguration. Technovation, 27(8), 426-432. http://dx.doi. org/10.1016/j.technovation.2006.08.003

Chen, J., Chen, Y., \& Vanhaverbeke, W. (2011). The influence of scope, depth, and orientation of external techonology sources on the innovative performances of Chinese firms. Technovation, 31(8), 362373. http://dx.doi.org/10.1016/j.technovation.2011.03.002

Chesbrough, H., \& Rosenbloom, R.S. (2002). The role of the business model in capturing value from innovation: Evidence from Xerox Corporations's technology spin-off companies. Industrial and Corporate Change, 11(3), 529-555. http://dx.doi.org/10.1093/ icc/11.3.529

Chesbrough, H. (2003a). The era of open innovation. MIT Sloan Management Review, 44(3), 35-41.

Chesbrough, H. (2003b). Open innovation: the new imperative for creating and profiting from technology. Boston, MA: Harvard Business School Press.

Chesbrough, H. (2003c). The logic of open innovation: Managing intellectual property. California Management Review, 45(3), 33-58. http://dx.doi.org/10.2307/41166175

Chesbrough, H. (2006). Open Innovation: A new paradigm for understanding industrial innovation. In Chesbrough, $\mathrm{H}$., Vanhaverberke,W., \& West, J. (eds.), Open Innovation: Researching a New Paradigm (pp.1-12). Oxford: University Press.

Chiaroni, D., Chiesa, V., \& Frattini, F. (2011).The Open Innovation Journal: How firms dynamically implement emerging innovation management paradigm. Technovation, 31(1), 34-43. http://dx.doi. org/10.1016/j.technovation.2009.08.007

Drucker, P. F. (1985). Innovation and Entrepreneurship. New York, NY: HarperCollins Publishers.

Eisenhardt, K.M., \& Martin, J. (2000). Dynamic capabilities: what are they? Strategic Management Journal, 21(10-11), 1105-1121. http://dx.doi.org/10.1002/1097-0266(200010/11)21:10/11<1105::aidsmj133>3.0.co;2-e

Ebersberger, B., Bloch, C., Herstad, S., \& Van de Velde, E. (2012). Open innovation practices and their effect on innovation performance. International Journal of Innovation and Technology Management, 9(6), p.1250040-1250040-23.http://dx.doi.org/10.1142/ s021987701250040x

Frankenberger, K., Wiblen, T., \& Gassman, O. (2014). The antecedents of open business models: an exploratory study of incumbents firms. R\&D Management, 44(2), 173-188. http://dx.doi.org/10.1111/ radm. 12040 
Gay, B. (2014). Open innovation, networking, and business model dynamics: the two sides. Journal of Innovation and Entrepreneurship, 3(2), 1-20. http://dx.doi.org/10.1186/2192-5372-3-2

Hatch, M. (1997). Organization Theory: Modern, Symbolic, and Postmodern Perspectives. Oxford: Oxford Press.

Hsieh, K., \& Tidd, J. (2012). Open versus close new service development: the influences of project novelty. Technovation, 32(11), 600-608. http://dx.doi.org/10.1016/j.technovation.2012.07.002

Huizingh, E.K.R.E. (2011). Open Innovation: State of Art and Future Perspective. Technovation, 31(1), 2-9. http://dx.doi.org/10.1016/j. technovation.2010.10.002

Klerkx, L., \& Aarts, N. (2013). The interactions of multiple champions in orchestrating innovation networks: Conflicts and complementarities. Technovation, 33(6-7), 193-210. http://dx.doi. org/10.1016/j.technovation.2013.03.002

Knudsen, M.P., \& Mortensen, T.B. (2011). Some immediate - but negative - effects of openness on product development performance. Technovation, 31(1), 54-64. http://dx.doi.org/10.1016/j. technovation.2010.07.002

Lee, S.M., Olson, D.L., \& Trimi, S. (2012). Innovative collaboration for value creating. Organizational Dynamics, 41(1), 7-12. http:// dx.doi.org/10.1016/j.orgdyn.2011.12.002

Lichtenthaler, U. (2010).Technology Exploitation in the context of open innovation: Finding the 'right' job for your technology. Technovation, 30(7-8), 429-435. http://dx.doi.org/10.1016/j. technovation.2010.04.001

Low, J. (2000). The value creation index. Journal of Intellectual Capital, 1(3), 252-262. http://dx.doi.org/10.1108/14691930010377919

Ndou, V., Vecchio, P.D., \& Schina, L. (2011). Open innovation networks: the role of innovative marketplaces for small and medium enterprises' value creation. International Journal of Innovation and Technology Management, 8(3), 437-453. http://dx.doi.org/10.1142/ s0219877011002404

Morgan, L., \& Finnegan, P. (2008). Deciding on open innovation: an exploration of how firms create and capture value with open source software. In León, G., Bernados, A., Casar, J., Kautz, K., \& DeGross, J. (Eds.), Open IT-Based Innovation: Moving Towards Cooperative IT Transfer and knowledge Diffusion (229-246). New York, NY: Springer.

Mortara, L., \& Minshall, T. (2011). How do large multinational companies implement open innovation. Technovation, 31(10-11), 586-597. http://dx.doi.org/10.1016/j.technovation.2011.05.002

Morris, M., Schindehutte, M., \& Allen, J. (2005). The entrepreneur's business model: Toward a unified perspective. Journal of Business Research, 58(6), 726-735. http://dx.doi.org/10.1016/j. jbusres.2003.11.001
Osterwalder, A., Pigneur, Y., \& Tucci, C.L. (2005). Clarifying business models: Origins, present, and future of the concept. Communications of the Association for Information Systems, 16(1), 1-25. Retrieved from http://aisel.aisnet.org/cais/vol16/iss1/1/

Porter, A.L., \& Newman, N.C. (2011). Mining External R\&D. Technovation, 31(4), 171-176. http://dx.doi.org/10.1016/j. technovation.2011.01.001

Saebi, T., \& Foss, N. (2014). Business models for open innovation: Matching heterogeneous open innovation strategies with business model dimensions. European Management Journal, 33(3), 201-213. http://dx.doi.org/10.1016/j.emj.2014.11.002

Shumpeter, J. (1934). The Theory of Economic Development. An inquiry into profits, capital, credit, interest, and the business cycle. Cambridge, MA: Harvard University Press.

Teece, D. (2007). Explicating dynamic capabilities: the nature and microfoundations of (sustainable) enterprise performance. Strategic Management Journal, 28(13), 1319-1350. http://dx.doi.org/10.1002/ smj. 640

Teece, D., Pisano, G., \& Shuen, A. (1997). Dynamic capabilities and strategic management. Strategic Management Journal, 18 (7), 509-533. http://dx.doi.org/10.1002/(sici)1097-0266(199708)18:7<509::aidsmj882>3.0.co;2-z

Tickle, M., Adebanjo, D., \& Michaelides, Z. (2011). Developmental approaches to B2B virtual communities.Technovation, 31(7), 296308. http://dx.doi.org/10.1016/j.technovation.2011.04.002

Tidd. J., Bessant, J., \& Pavitt, K. (2005). Managing innovation: integrating technological, market and organizational change. West Sussex: John Wiley \& Sons.

Touraine, A. (1997). Crítica da Modernidade. Petrópolis, RJ: Vozes.

Van de Vrande, V., De Jong, J.P.J., Vanhaverbeke, W., \& De Rochemont, M. (2009). Open Innovation in SMEs: Trends, motives and management challenges. Technovation, 29(6-7), 423-437. http:// dx.doi.org/10.1016/j.technovation.2008.10.001

Weiblen, T. (2014). The open business model: understanding an emergent concept. Journal of Multi Business Model Innovation and Technology, 2(1), 35-66. DOI:10.13052/jmbmit2245-456X.212

West, J., Salter, A., Vanhaverbeke, W., \& Chesbrough, H. (2014). Open innovation: the next decade. Research Policy, 43(5), 805-811. http:// dx.doi.org/10.1016/j.respol.2014.03.001

Yin, R.K. (2005). Estudo de Caso-Planejamento e Método. Porto Alegre, RGS: Bookman.

Young, B., Hewitt-Dundas, N., \& Roper, S. (2008). Intellectual Property management in publicly funded R\&D centres - A comparison of University-based and company-based research centres. Technovation, 28(8), 473-484. http://dx.doi.org/10.1016/j.technovation.2008.02.004 